\title{
Alan Stewart
}

\section{Shakespeare's Letters}

Oxford: Oxford University Press. 2008. Pp. xvi, 405.

Peace, print, and Protestantism seemed to the author of a famous textbook to be defining characteristics of the England shaped in the century before Shakespeare's birth. The formulation is neat and memorable; but rather than print, many historians might now prefer to say paper, whose increasing availability from the fifteenth century onwards supported textual production of new kinds and in new quantities, in manuscript as well as print. Alan Stewart's work has for some years led him through a number of paper-rich early modern environments, from schoolrooms to the closet, and from the records in the Castle of Alma to those used and cited in the Overbury murder case. He has in particular attended to letters, directing the ongoing Francis Bacon Correspondence Project and co-curating the Folger exhibition Letterwriting in Renaissance England.

Stewart now brings his understanding of early modern English letter writing to Shakespeare's letters. As a title, this phrase invites a double-take: Shakespeare's Letters could be a very short book, like The Snakes of Ireland. Shakespeare must have written back from the metropolis where he worked to his home town, where his wife and children lived and he maintained business and property interests. But only one letter to him has survived, and none that he sent.

Romantic responses to this absence of a Shakespeare correspondence frame Shakespeare's Letters, which begins with William Henry Ireland's production of letters from Elizabeth I and others to the Bard, and ends with the story of a signet ring with the initials ws, apparently found at Stratford upon Avon. But Stewart does not linger upon this theme - for "Shakespeare's letters survive in abundance." One hundred and eleven of them appear in his plays; all but five of the plays in the First Folio feature letters. Stewart's aim is "to capture the particular nature of the letters on Shakespeare's stage," in both historical and theatrical terms. He succeeds with considerable éclat. Readers of this book will never see those hundred and eleven letters in the same way again.

The book begins with a materially oriented overview of the letters handled on Shakespeare's stage and known to his first audiences: paper, ink, and wax; miseen-page and folding. Strikingly important here is the person of the messenger, who carries the letter to the hands of its addressee, and may supplement its contents with a spoken message or bring back an account of its reception. Stewart rejects the Erasmian fantasy of the letter as making its sender incorporeally present to its 
recipient; the letter-writing relationship in Shakespeare's world employs a vital, identifiable go-between.

Stewart's second chapter, on letters in the Roman plays, comments not only on their anachronisms (Jonson was much more careful, as one would expect) but on their messengers. Brutus is impressed by letters thrown in at his window, coming-suspiciously_without a messenger; Cleopatra strikes the messenger who brings her news of Antony's marriage, "hales him up and down," and draws a knife on him. In contrast with the "documentary culture" exemplified by Octavius, who is "significantly first encountered by the audience in the act of 'reading a letter' from Alexandria," she understands news in bodily terms. Antony is insensitive to the protocols of correspondence. A vital letter of his is carried, inappropriately, by his schoolmaster, and as Octavius complains, he "Did pocket up my letters" (as Stewart points out, the early modern English letter was a folded single sheet which might well be less than three inches by two, easily pocketed). In his suicide, reported as committed by "that self hand Which writ his honour in the acts it did," he asks for the help of Eros, the secretary of his last generous letter to Enobarbus. "Antony does not do his own writing," muses Stewart, "so perhaps he did not write his own honour."

The third chapter, "Shakespeare and the Carriers," breathes new life into a scene which has been cut in productions from the 1620 s to the present day. Why care about the carriers of 1 Henry IV Act II Scene i ? Stewart begins his answer by reading the surviving letter to Shakespeare, from Richard Quiney of Stratford upon Avon, dated from the Bell in Carter Lane, London. Why does the letter bear that address, and why does it survive among Quiney's papers? The answer is that Quiney kept the letter because he met Shakespeare at the Bell on the day of its composition, so that there was no need to send it, and that the Bell was the London inn used by the Stratford carrier and therefore used as a London base by men of Stratford. The carrier was their lifeline out of London; he was also a vulnerable figure, who might be held legally responsible for goods stolen from him. For the numerous migrant workers in the audience of 1 Henry $I V$, the carrier scene made it clear that the robbery at Gadshill was an attack, perhaps a financially ruinous one, on the very men on whom they depended for contact with their home communities.

Quiney's letter asks Shakespeare for the loan of the substantial sum of 30 pounds. As the next chapter argues, this request fits into a network of other financial transactions which can be reconstructed from Quiney's correspondence. This is the world of the Merchant of Venice, a play whose "treatment of credit is inextricably linked to its depiction of letters." The sealed bond between Shylock and Antonio is 
a kind of letter, contrasted, as Stewart argues, with oral agreements and promises, and associated with other letters in the play.

"More letters appear on stage in King Lear than in any other Shakespearean play," and these letters and their messengers are discussed in the next chapter. Two chapters on Hamlet follow, and the first of these contrasts with the account of Lear, partly because it has a single big argument rather than unpacking multiple passages individually, and partly because it is not, to my mind, entirely convincing. Here, Stewart proposes "that Ophelia understands that she and Hamlet are to be married; and that the letter that he sends her constitutes both the most compelling piece of evidence of this, and the most disastrous proof of Ophelia's acquiescence to his sexual attentions." But is this true? The "stage tradition" which Stewart sees as having developed a "shorthand for determining whether or not parties had consented to marriage" seems to come down to some passages from Ralph Roister Doister which show that a woman's receiving love letters is dangerously indecorous, and one to the same effect from Two Gentlemen of Verona. Hamlet's one certain letter to Ophelia does not hint at marriage, and it is not clear that further letters are among the "remembrances" she returns to him.

A second chapter on Hamlet reflects on the forging of the letter which brings Rosencrantz and Guildenstern to their deaths, and on the themes of inscription and erasure, with particular reference to Hamlet's successive clearing of "the table of my memory" and setting down in his tables "That one may smile and smile and be a villain." It ends with the reflection that if, in the course of the explanations he promises to make to Fortinbras after the play, Horatio is to produce the letter by which Claudius hoped to have Hamlet destroyed, the English ambassadors will probably produce Hamlet's forged letter, to his posthumous discredit-but "perhaps Horatio could take comfort from the fact that ... a paper letter ... [is] very easy to conceal and destroy," so perhaps he will suppress Claudius's letter after all. This is an oddly whimsical line to be taking at the end of a final chapter. If the best arguments in both these chapters on Hamlet had been brought together in one, the book might have ended with more of a bang.

Be that as it may, this is a resoundingly successful book, alive with intelligence, and written in consistently excellent prose. One of the all-star team whose praise appears on the dustjacket, Stanley Wells, calls Shakespeare's Letters "brilliant and highly enjoyable.” It is.

JOHN CONSIDINE, University of Alberta 